\title{
SEWAGE SLUDGE LEVELS ON THE DEVELOPMENT AND NUTRITION OF SUNFLOWER PLANTS
}

\author{
Thomaz Figueiredo Lobo* ${ }^{*}$ and Helio Grassi Filho \\ Faculdade de Ciências Agronômicas de Botucatu - UNESP - Caixa Postal 237, CEP 18610-307, \\ Botucatu - SP, Brasil. *Corresponding author: thomaz@fca.unesp.br
}

\begin{abstract}
This study aimed to evaluate the effect of substituting chemical nitrogen (N) fertilization for equivalent $\mathrm{N}$ levels from sewage sludge of Wastewater Treatment Plant (WTP) on sunflower plant development. Nutrient levels in physiologically mature leaves and seeds, besides nutrient exportation during a 130-day assay, were also assessed. The experiment was carried out in $100 \mathrm{~m}^{2}$ permanent plots at São Manuel Farm, which belongs to School of Agronomical Sciences, São Paulo State UniversityUNESP, Botucatu, São Paulo State, Brazil. The farm is located in the municipality of São Manuel, São Paulo State. Experimental design was in randomized blocks including 5 treatments and 5 replicates. Treatments were: $\mathrm{T} 1$ - chemical $\mathrm{N}$ fertilization according to the recommendation for the culture; $\mathrm{T} 2-50 \% \mathrm{~N}$ from sewage sludge and $50 \% \mathrm{~N}$ from chemical fertilization; T3 $-100 \% \mathrm{~N}$ from sewage sludge; $\mathrm{T} 4-150 \% \mathrm{~N}$ from sewage sludge; T5 - 200\% N from sewage sludge. For all treatments, equal amounts of $\mathrm{P}$ and $\mathrm{K}$ fertilization were applied. Treatments differed for plant height from 21 to 64 days, stem diameter from 28 to 57 days, and leaf number from 21 to 38 days. Seed nutrient levels slightly varied; however, the quantities of exported $\mathrm{N}, \mathrm{P}, \mathrm{Mg}, \mathrm{Fe}$ and $\mathrm{Zn}$ varied as sewage sludge levels increased.
\end{abstract}

Keywords: manure, biosolids and nitrogen

\section{INTRODUCTION}

Sewage sludge is a residue from biological wastewater treatment plants, where domestic waste predominates over industrial one and heavy metal levels and pathogens are within the acceptable range for agricultural use (CONAMA, 2006). However, the final disposal of sewage sludge is a worldwide concern since its produced volume is increasing.

As an alternative, this residue has already been used for agriculture in numerous countries. The collection and treatment system for domestic waste is one of the basic assumptions for a healthy environment, providing life quality and environment preservation (Andreoli et al., 1997).

Sewage sludge application was studied by Prado and Natale (2005) in passionflower culture. In a greenhouse, plants were subjected to sewage sludge levels of up to $30 \mathrm{mg} \mathrm{ha}^{-1}$ (dry matter basis) and yielded quadratic responses for dry matter production and nutrient accumulation. In another study, a 4-fold $\mathrm{N}$ demand increased dry phytomass 
production and $\mathrm{N}$ level in Brachiaria decumbens leaves (Araújo et al., 2009). In bean plants, $\mathrm{N}$ levels increased as the added sewage sludge levels were higher (Barros et al., 2002).

Since sewage sludge is rich in nutrients, mainly nitrogen (N) and phosphorous $(\mathrm{P})$, it has been used in many countries as a substitute for chemical fertilizers (Binder et al., 2002). Mineral nutrition is an important environmental factor and $\mathrm{N}$ is the macronutrient mostly required by cultures since plant growth and development are highly dependent on the availability of this nutrient. Such high dependence is due to the roles of $\mathrm{N}$ in plant metabolism, being a constituent of chlorophyll molecules, nucleic acids, amino acids and proteins (Taiz and Zeiger, 2004; Malavolta, 2006; Epstein and Bloom, 2006).

Lobo and Grassi Filho (2007) reported that in sunflower culture $\mathrm{N}$ from mineral fertilization can be substituted for that from sewage sludge, significantly increasing grain productivity, oil and dry matter yield.

Thus, the present work aimed to evaluate the effect of substituting chemical nitrogen fertilization for equivalent levels of $\mathrm{N}$ from WTP sewage sludge on sunflower development parameters, as well as to assess nutrient levels in physiologically mature leaves and seeds, including nutrient exportation.

\section{MATERIAL AND METHODS}

This study was carried out at São Manuel Experimental Farm, which belongs to School of Agronomical Sciences, São Paulo State University-UNESP, Botucatu, São Paulo State, Brazil. The farm is located in São Manuel Municipality, São Paulo State $\left(22^{\circ} 25^{\prime} \mathrm{S}\right.$; $48^{\circ} 34^{\prime} \mathrm{W}$ ), at an altitude of $750 \mathrm{~m}$ above sea level. According to Köppen classification, the climate in the study region is mesothermal, Cwa, i.e. humid subtropical including drought in the winter and rain from November to April, and the average annual rainfall in that municipality is $1,433 \mathrm{~mm}$. The air relative humidity is $71 \%$, with annual average temperature of $23^{\circ} \mathrm{C}$. Meteorological data and classification were supplied by the Department of Natural Resources, Environmental Sciences Area, College of Agronomical Sciences-FCA, UNESP, Botucatu. The soil physical and chemical characteristics were already described by Lobo and Grassi Filho (2007).

Prior to the experiment stablishment, chemical analyses were done for the soil in the depth ranges of $0-20$ to $20-40 \mathrm{~cm}$, according to Raij et al. (2001). These results are shown in Tables 1 and 2.

$\mathrm{P}_{2} \mathrm{O}_{5}$ and $\mathrm{K}_{2} \mathrm{O}$ fertilizations were done at planting according to the analysis of soil with $30 \mathrm{~kg} \mathrm{ha}_{-1} \mathrm{P}_{2} \mathrm{O}_{5}$ in the form of simple superphosphate and $30 \mathrm{~kg} \mathrm{ha}$ $\mathrm{K}_{2} \mathrm{O}$ in the form of potassium chloride.

Experimental design was in randomized blocks constituted of 5 treatments and 5 replicates, as defined by Pimentel Gomes (2000): T1, chemical nitrogen fertilization of $50 \mathrm{~kg} \mathrm{ha}-1,10 \mathrm{~kg}$ being applied at planting and $40 \mathrm{~kg} \mathrm{~N}$ in cover fertilization, which is recommended for sunflower culture in São Paulo State, Brazil - 100\% chemical nitrogen (urea); $\mathrm{T} 2,50 \%$ sewage-sludge nitrogen and $50 \%$ chemical nitrogen, cover fertilization (urea); T3, 100\% sewage-sludge nitrogen fertilization, as recommended for the culture; T4, 150\% sewage-sludge nitrogen fertilization; T5, 200\% sewage-sludge nitrogen fertilization.

The used sewage sludge was from the Sewage Treatment Plant in the city of Jundiaí, São Paulo State. It was collected from samples composed of sludge presenting the characteristics shown in Table 3 (LANARV, 1988). 
The analysis was carried out in the Laboratory of Fertilizers and Correctors, Department of Natural Resources / Soil Sciences, School of Agronomical Sciences, Botucatu, São Paulo State.

Plot size, spacing, sewage-sludge $\mathrm{N}$ calculation, cultivar, sewage sludge chemical characteristics, and the remaining culture procedures were previously described by Lobo and Grasi Filho (2007).
Total rainfall during the crop season was $507 \mathrm{~mm}$, reaching $296 \mathrm{~mm}$ in the first month of sowing.

Plant development parameters (plant height, leaf number and stem diameter) were weekly evaluated until the flowering phase. Plant height, stem diameter, leaf number, and macro and micronutrient levels in the leaves were analyzed together for 10 plants randomly distributed in each plot.

Table 1. Chemical characteristics of the soil where the experiment was developed (basic).

\begin{tabular}{|c|c|c|c|c|c|c|c|c|c|c|c|}
\hline \multirow{2}{*}{$\begin{array}{l}\text { Depth } \\
\mathrm{cm}\end{array}$} & \multirow{2}{*}{$\begin{array}{l}\mathrm{pH} \\
\mathrm{CaCl}_{2}\end{array}$} & \multirow{2}{*}{$\begin{array}{l}\text { O.M. } \\
\text { g dm}^{-3}\end{array}$} & \multirow{2}{*}{$\begin{array}{l}\mathrm{P}(\text { res.) } \\
\mathrm{mg} \mathrm{dm}^{-3}\end{array}$} & $\mathrm{H}+\mathrm{Al}$ & $\mathrm{Al}^{3+}$ & $\mathrm{K}^{+}$ & $\mathrm{Ca}^{2+}$ & $\mathrm{Mg}^{2+}$ & SB & CEC & \multirow{2}{*}{$\begin{array}{l}\text { BS } \\
\%\end{array}$} \\
\hline & & & & \multicolumn{7}{|c|}{------------------------ $\mathrm{mmol}_{\mathrm{c}} \mathrm{dm}^{-3}$-------------------- } & \\
\hline $0-20$ & 6.1 & 12 & 20 & 13 & 1 & 1.9 & 19 & 12 & 33 & 46 & 71 \\
\hline $20-40$ & 6.1 & 7 & 6 & 13 & 1 & 1.6 & 17 & 9 & 28 & 41 & 68 \\
\hline
\end{tabular}

$\mathrm{CEC}=\mathrm{Ca}+\mathrm{Mg}+\mathrm{K}+\mathrm{H}+\mathrm{Al} ; \mathrm{SB}=\mathrm{Ca}+\mathrm{Mg}+\mathrm{K} ; \mathrm{BS}=\left((\mathrm{SB} / \mathrm{CEC})^{*} 100\right)$. Raij et al. (2001).

Table 2. Chemical characteristics of the soil where the experiment was developed (micronutrients).

\begin{tabular}{lccccc}
\hline Depth & $\mathrm{B}$ & $\mathrm{Cu}$ & $\mathrm{Fe}$ & $\mathrm{Mn}$ & $\mathrm{Zn}$ \\
\cline { 2 - 6 } $\mathrm{cm}$ & & ----------------- & $\mathrm{mg} \mathrm{dm}^{-3}$ & ---------------- & \\
\hline $0-20$ & 0.11 & 1.0 & 20 & 7.7 & 1.2 \\
$20-40$ & 0.09 & 0.9 & 13 & 4.1 & 1.2 \\
\hline
\end{tabular}

Table 3. Chemical characteristics of the sewage sludge used in the experiment.

\begin{tabular}{|c|c|c|c|c|c|c|c|c|c|c|c|c|c|c|}
\hline $\mathrm{N}$ & $\begin{array}{ll}\mathrm{P}_{2} \mathrm{O}_{5} & \mathrm{~K}_{2} \mathrm{O}\end{array}$ & Humidity. & $\mathrm{MO}$ & $\mathrm{C}$ & $\mathrm{Ca}$ & $\mathrm{Mg}$ & $\mathrm{S}$ & $\mathrm{Na}$ & $\mathrm{Cu}$ & $\mathrm{Fe}$ & $\mathrm{Mn}$ & $\mathrm{Zn}$ & $\mathrm{C} / \mathrm{N}$ & $\mathrm{pH}$ \\
\hline- & & - & & & & & & - & 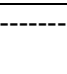 & $-\mathrm{mg} \mathrm{kg}$ & & ---- & & \\
\hline 31.8 & 17.2 & 675.8 & 550 & 306 & 12.5 & 2.2 & 45.6 & 1520 & 812 & 31650 & 3400 & 2150 & $10 / 1$ & 4.3 \\
\hline
\end{tabular}

Plant height was first measured at $20 \mathrm{~d}$ after sowing and weekly repeated until 70 days by using a tape measure of $100 \mathrm{~cm}$ maximal height; from this maximal point a $2 \mathrm{~m}$ ruler was employed. During the vegetative development, height was assessed from the soil to the insertion of the last unfolded leaf, while in the reproductive phase it was measured from the soil to the capitulum insertion. Stem diameter $(\mathrm{cm})$ was first measured at 34 days after sowing and weekly repeated until 70 days by using a caliper from the soil. Leaf number was also weekly determined from 27 to $56 \mathrm{~d}$ after sowing by counting the number of completely unfolded leaves in the plant.

For macro and micronutrient analysis leaves were harvested at the beginning of flowering (Malavolta et al., 1997), and 
the $4^{\text {th }}$ leaf from the upper part of the plant was collected. Harvested leaves were analyzed for $\mathrm{N}, \mathrm{P}, \mathrm{K}, \mathrm{Ca}, \mathrm{Mg}, \mathrm{S}, \mathrm{B}, \mathrm{Cu}$, $\mathrm{Fe}, \mathrm{Mn}$ and $\mathrm{Zn}$ levels, according to the methodology described by Malavolta et al. (1997).

Seeds were collected from 10 plants in the stage R9, when capitula were turned down. They were dried in a forced aeration oven at $60^{\circ} \mathrm{C} \pm 5^{\circ} \mathrm{C}$ for $7 \mathrm{~d}$ and ground by using a Willey-type mill. The ground material was stored in paper bags and sent for macro and micronutrient analysis at the Laboratory of Plant Mineral Nutrition, Department of Natural Resources/Soil Sciences, FCA/UNESP, where $\mathrm{N}, \mathrm{P}, \mathrm{K}, \mathrm{Ca}, \mathrm{Mg}, \mathrm{S}, \mathrm{B}, \mathrm{Cu}, \mathrm{Fe}, \mathrm{Mn}$ and $\mathrm{Zn}$ levels were determined according to the methodology of Malavolta et al. (1997). Results were used to calculate the levels of nutrients exported by the seeds as follows: the level of each element was multiplied by each plot productivity in 1 ha.

Data were subjected to comparison of means by Tukey's test at 5\% probability level, according to Statistical Analysis System procedures (SAS Institute, 2001).

\section{RESULTS AND DISCUSSION}

Mean plant heights on emergence days $14,21,28,38,44,50,57$ and 64 are represented in Figure 1. From 21 to $38 \mathrm{~d}$, T4 and T5 had superior heights, compared to the other treatments. From 38 to 50 days, T5 presented the highest height. From $50 \mathrm{~d}$ after emergence, mean heights were higher in T5 and T2. In any moment, T5 was inferior to the other treatments, providing better land closing and not allowing weeds; in addition, the increased height development could protect the soil for a longer period. Salvador (2006) used sludge containing $0.63 \% \mathrm{~N}$ and $66.73 \%$ dry matter and at 83 days after planting the height of maize plants receiving 40 $\mathrm{mg} \mathrm{ha}{ }^{-1}$ sewage sludge on a wet weight basis was equal to that of plants receiving complete mineral fertilization.

Similarly, Tanaka (1981) reported a beneficial effect of $\mathrm{N}$ on sunflower culture, increasing plant height. Biscaro et al. (2008) obtained a quadratic response of $\mathrm{N}$ application for height at $30 \mathrm{~d}$ after emergence; the application of $69 \mathrm{~kg} \mathrm{ha}^{-1}$ $\mathrm{N}$ led to a $40.6 \mathrm{~cm}$ height. At $45 \mathrm{~d}$ after emergence, $114.7 \mathrm{~cm}$ height was obtained with the application of $72.9 \mathrm{~kg} \mathrm{ha}^{-1} \mathrm{~N}$. In the latter, cover nutrient application was important to plant growth and resulted in a good plant size, without lodging and with easy management and harvest due to the appropriate height.

As shown in Figure 2, at $28 \mathrm{~d}$ after emergence stem diameter was significantly greater in $\mathrm{T} 5(1.4 \mathrm{~cm})$ than in T1 $(1.1 \mathrm{~cm}), \mathrm{T} 2(1.1 \mathrm{~cm})$ and T3 $(1.2$ $\mathrm{cm})$. At 38 and $44 \mathrm{~d}$, T5 had the greatest diameter (2.0 and $2.4 \mathrm{~cm}$, respectively). At 50 and $57 \mathrm{~d}$, respectively, diameter was statistically equal in T2 (2.4 and 2.6 $\mathrm{cm})$ and T5 $(2.7$ and $2.8 \mathrm{~cm})$, which was probably due to the nitrogen fertilization in T2; besides, T5 diameters were statistically greater than those of T1 $(2.4$ and $2.4 \mathrm{~cm}), \mathrm{T} 3(2.2$ and $2.4 \mathrm{~cm})$ and T4 $(2.3$ and $2.5 \mathrm{~cm})$.

Biscaro et al. (2008) also applied $\mathrm{N}$ up to the estimated maximal level of $47.8 \mathrm{~kg}$ $\mathrm{ha}^{-1}$ in sunflower plants and obtained increased stem diameters, which reached a mean growth of $18.4 \mathrm{~mm}$. Stem diameter is an important characteristic for sunflower plants since it allows less lodging, facilitating management and harvest.

As regards leaf number (Figure 3), already in the first evaluation, at $21 \mathrm{~d}$ after emergence, T2, T3, T4 and T5 had a mean leaf number of 12.8, 12.6, 12.8 and 13.8, respectively, and did not differ statistically; T1 had a mean number of 11 , 
Rev. Cienc. Suelo Nutr. / J. Soil. Sci. Plant Nutr. 9(3): 245-255 (2009)

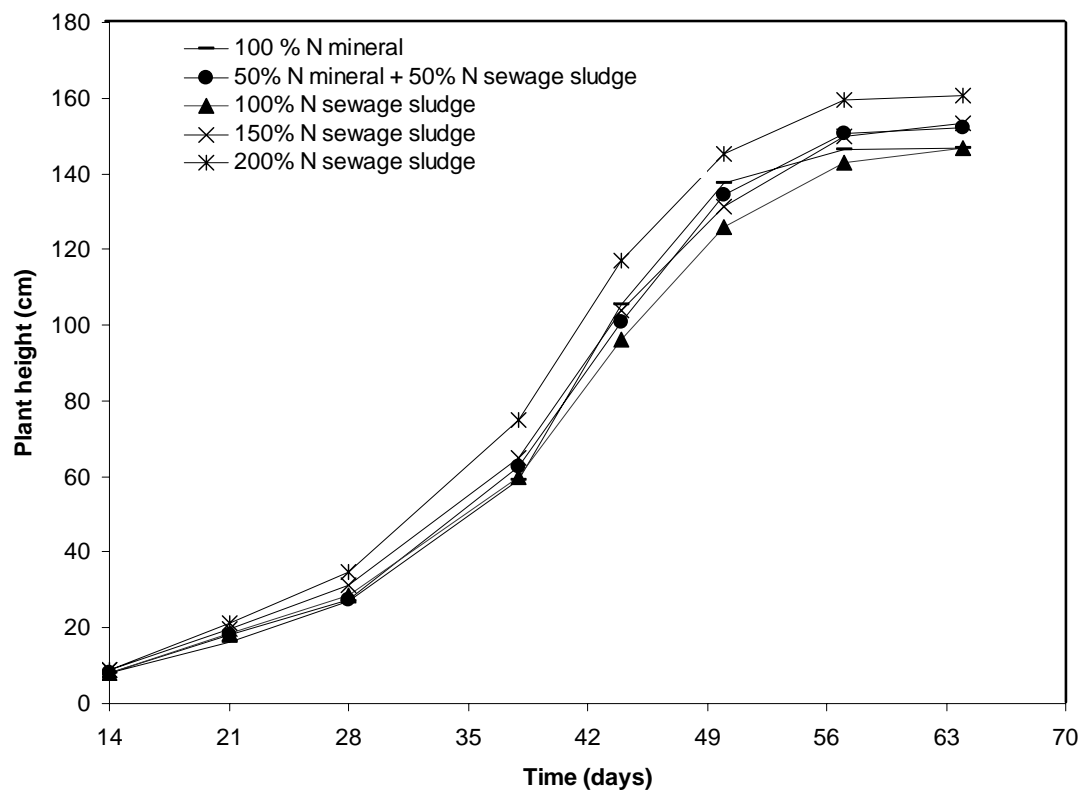

Figure 1. Mean height of sunflower plants expressed as days after emergence

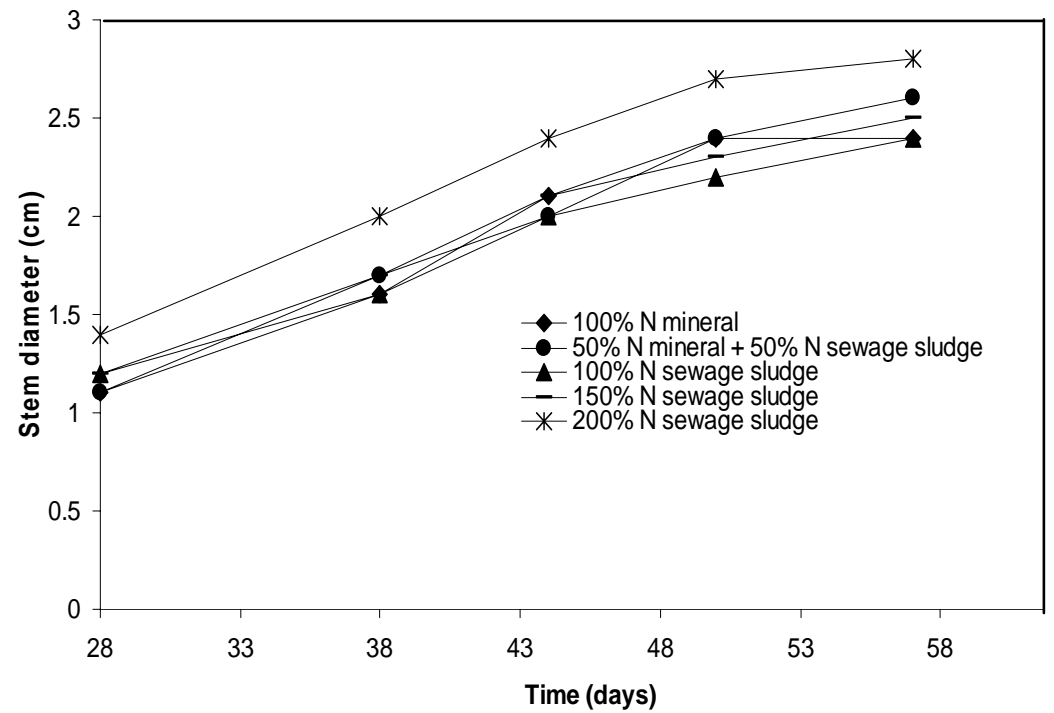

Figure 2. Mean stem diameter of sunflower plant from 28 to 57 days after emergence 


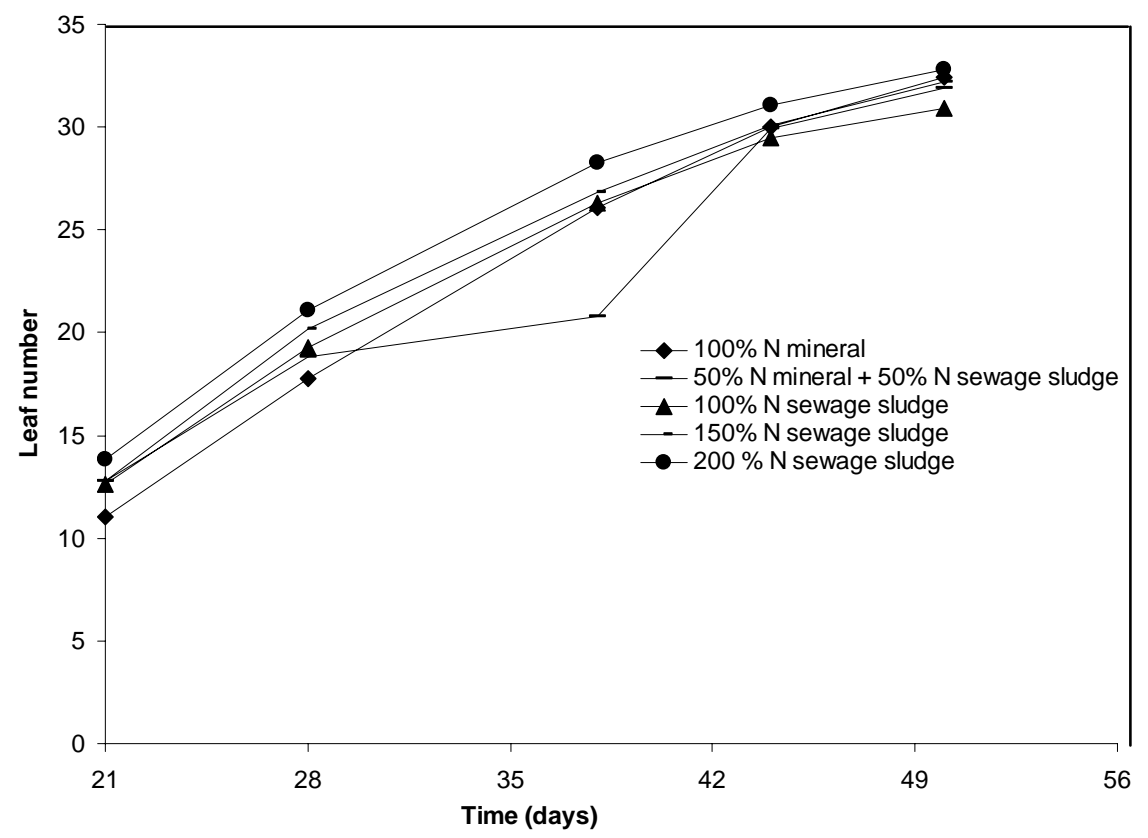

Figure 3. Mean leaf number of sunflower plants from 21 to 50 days after emergence

which was statistically smaller than that of the other treatments. At $28 \mathrm{~d}$ after emergence, T5 had 21.1 leaves per plant and did not differ from T4, which had 20.2 leaves per plant; in addition, the mean leaf number of T5 was larger than that of T1, T2 and T3, which presented 17.8, 18.8 and 19.3 leaves per plant, respectively, and leaf number in $\mathrm{T} 3$ was superior to that in T1. At 44 and $50 \mathrm{~d}$, all treatments were statistically equal, presenting a mean leaf number of 30.1 and 32, respectively; these latter values probably did not vary due to the $\mathrm{N}$ fertilization in $\mathrm{T} 1$ and $\mathrm{T} 2$.

According to Biscaro et al. (2008), there is a significant effect of cover $\mathrm{N}$ application in sunflower. At $30 \mathrm{~d}$ after emergence, those authors obtained a quadratic response of the applied $\mathrm{N}$ levels with the highest level of $80 \mathrm{~kg}$ ha-1, and leaf number increased up to 15.5 leaves per plant. A significant effect was also verified at $45 \mathrm{~d}$ after emergence, including a quadratic response of $\mathrm{N}$ level with the highest studied level $\left(80 \mathrm{~kg} \mathrm{ha}^{-1}\right)$, resulting in 29.2 leaves per plant. This indicates that the leaf number per plant was influenced by cover $\mathrm{N}$ application, following plant growth and producing leaves until the plant reached its maximal growth.

Primary macronutrients $(\mathrm{N}, \mathrm{P}$ and $\mathrm{K})$ in the leaves did not statistically differ among treatments. $\mathrm{N}$ levels were adequate (35-50 $\mathrm{g} \mathrm{kg}^{-1}$ ), and the mean among treatments was $34 \mathrm{~g} \mathrm{~kg}^{-1}$, indicating no problem due to the lack of $\mathrm{N}$ in the leaf harvest period. $\mathrm{P}$ mean among treatments was $5 \mathrm{~g} \mathrm{~kg}^{-1}$ and did not vary; however, the adequate level is from 2.9 to $4.5 \mathrm{~g} \mathrm{~kg}^{-1}$ (Castro and Oliveira, 2005). $\mathrm{K}$ mean among treatments was $40.3 \mathrm{~g} \mathrm{~kg}^{-1}$ and all treatments had adequate levels $(31-45 \mathrm{~g}$ $\mathrm{kg}^{-1}$ ) (Castro and Oliveira, 2005), as shown in Table 4. 
Table 4. Mean levels of N, P, K, Ca, Mg and S in sunflower leaves

\begin{tabular}{|c|c|c|c|c|c|c|}
\hline \multirow[t]{2}{*}{ Treatment } & $\mathbf{N}$ & $\mathbf{P}$ & $\mathbf{K}$ & $\mathbf{C a}$ & Mg & $\mathbf{S}$ \\
\hline & \multicolumn{6}{|c|}{. } \\
\hline T1 & $35.8 \mathrm{a}$ & $4.6 \mathrm{a}$ & $41.2 \mathrm{a}$ & $19.0 \mathrm{a}$ & $5.9 \mathrm{a}$ & $3.2 \mathrm{a}$ \\
\hline T2 & $36.0 \mathrm{a}$ & $5.1 \mathrm{a}$ & $40.2 \mathrm{a}$ & $21.6 \mathrm{a}$ & $6.8 \mathrm{a}$ & $3.6 \mathrm{a}$ \\
\hline T3 & $32.8 \mathrm{a}$ & $5.2 \mathrm{a}$ & $42.6 \mathrm{a}$ & $20.4 \mathrm{a}$ & $6.5 \mathrm{a}$ & $3.7 \mathrm{a}$ \\
\hline T4 & $33.4 \mathrm{a}$ & $5.0 \mathrm{a}$ & $40.6 \mathrm{a}$ & $20.6 \mathrm{a}$ & $7.0 \mathrm{a}$ & $3.9 \mathrm{a}$ \\
\hline T5 & $32.2 \mathrm{a}$ & $4.9 \mathrm{a}$ & $36.8 \mathrm{a}$ & $20.4 \mathrm{a}$ & $6.3 \mathrm{a}$ & $3.8 \mathrm{a}$ \\
\hline $\mathbf{F}$ & $1.99^{\mathrm{NS}}$ & $0.88^{\mathrm{NS}}$ & $2.53^{\mathrm{NS}}$ & $0.45^{\mathrm{NS}}$ & $2.09^{\mathrm{NS}}$ & $2.34^{\mathrm{NS}}$ \\
\hline Mean & 34.0 & 5.0 & 40.3 & 20.4 & 6.5 & 3.6 \\
\hline CV & 8.1 & 11.8 & 7.5 & 15.1 & 10.1 & 10.7 \\
\hline
\end{tabular}

Equal lowercase letters in the columns do not differ according to the Tukey's test at 5\% probability level. NS: Non-Significant

Secondary macronutrients $(\mathrm{Ca}, \mathrm{Mg}$ and $\mathrm{S})$ did not differ among treatments and were present at adequate levels: $\mathrm{Ca}, 19$ to $32 \mathrm{~g}$ $\mathrm{kg}^{-1} ; \mathrm{Mg}, 5.1$ to $9.4 \mathrm{~g} \mathrm{~kg}^{-1}$; and $\mathrm{S}, 3$ to 6.4 $\mathrm{g} \mathrm{kg}^{-1}$ concerning leaf levels for sunflower culture (Castro and Oliveira, 2005). The vaules of $\mathrm{Ca}, \mathrm{Mg}$ and $\mathrm{S}$ were adequate: 20.4, 6.5 and 3.6, respectively.

According to Castro and Oliveira (2005), the adequate levels for micronutrients are: $\mathrm{B}, 35-80 \mathrm{mg} \mathrm{kg}^{-1}$; $\mathrm{Cu}$, 24-42 $\mathrm{mg} \mathrm{kg}^{-1}$; Fe, 120-235 mg kg-1; Mn, $55-180 \mathrm{mg} \mathrm{kg}^{-1}$; and $\mathrm{Zn}, 29-43 \mathrm{mg} \mathrm{kg}^{-1}$. B levels did not vary among treatments and were adequate $\left(69.76 \mathrm{mg} \quad \mathrm{kg}^{-1}\right)$. Although $\mathrm{Cu}$ levels did not vary among treatments, they were slightly low (22.72 $\left.\mathrm{mg} \mathrm{kg}{ }^{-1}\right) . \mathrm{Fe}$ and $\mathrm{Mn}$ levels did not vary among treatments and were adequate (134.84 mg kg-1 and $143.76 \mathrm{mg} \mathrm{kg}^{-1}$, respectively). Zn was the only element that differed with sewage sludge application since the latter contained a high level of this nutrient and the soil already had $1.2 \mathrm{mg} \mathrm{dm}-3 \mathrm{Zn}$, which is considered high (Raij et al., 1997). There was a significant difference between the treatment that did not receive sewage sludge and the ones that received it. The lowest sewage sludge level contained $5.2 \mathrm{~kg} \mathrm{ha}^{-1} \mathrm{Zn}$, and all leaf levels had high concentration of this element. The high $\mathrm{Zn}$ level in the soil and in the sewage sludge probably inhibited $\mathrm{Cu}$ absorption; thus, in the leaves $\mathrm{Zn}$ levels were high and $\mathrm{Cu}$ levels low (Table 5).

As shown in Table 6, macronutrient levels in the seeds did not vary. However, macronutrient exportation significantly differed as productivity increased, except for $\mathrm{Ca}$ which did not vary among treatments. This can be explained by the original high level of $\mathrm{Ca}$ in the soil, when the needed $\mathrm{Ca}$ level for sunflower to complete its cycle is too small, $9 \mathrm{~kg} \mathrm{ha}^{-1}$ (Castro and Oliveira, 2005).

As regards micronutrients, the only element that showed significant differences among treatments was $\mathrm{Zn}$ (Table 8). Micronutrient exportation by the seeds (Table 9) significantly increased as the applied sewage sludge levels were higher, except for Cu. Vieira et al. (2005) noticed that in soybean plants, up to 6 ton $\mathrm{ha}^{-1}$ sewage sludge on the dry matter basis did not increase $\mathrm{Cu}, \mathrm{Zn}$ and Fe levels in the grains. 
Table 5. Mean levels of B, $\mathrm{Cu}, \mathrm{Fe}, \mathrm{Mn}$ and $\mathrm{Zn}$ in sunflower leaves

\begin{tabular}{|c|c|c|c|c|c|}
\hline \multirow[t]{2}{*}{ Treatment } & B & $\mathbf{C u}$ & $\mathbf{F e}$ & Mn & Zn \\
\hline & \multicolumn{5}{|c|}{ 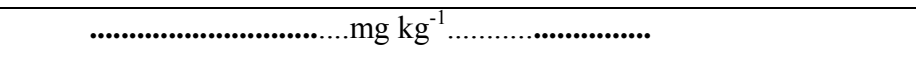 } \\
\hline T1 & $70.6 \mathrm{a}$ & $22.8 \mathrm{a}$ & $144.4 \mathrm{a}$ & $130.6 \mathrm{a}$ & $45.6 \mathrm{~b}$ \\
\hline T2 & $75.4 \mathrm{a}$ & $24.0 \mathrm{a}$ & $143.8 \mathrm{a}$ & $141.2 \mathrm{a}$ & $49.8 \mathrm{a}$ \\
\hline T3 & $60.2 \mathrm{a}$ & $22.0 \mathrm{a}$ & $129.2 \mathrm{a}$ & $156.8 \mathrm{a}$ & $47.2 \mathrm{a}$ \\
\hline T4 & $68.0 \mathrm{a}$ & $22.4 \mathrm{a}$ & $132.4 \mathrm{a}$ & $147.0 \mathrm{a}$ & $50.4 \mathrm{a}$ \\
\hline T5 & $74.6 \mathrm{a}$ & $22.4 \mathrm{a}$ & $124.4 \mathrm{a}$ & $143.2 \mathrm{a}$ & $50.6 \mathrm{a}$ \\
\hline $\mathbf{F}$ & $2.21^{\mathrm{NS}}$ & $0.71^{\mathrm{NS}}$ & $2.25^{\mathrm{NS}}$ & $0.29^{\mathrm{NS}}$ & $1.98 *$ \\
\hline Mean & 69.76 & 22.72 & 134.84 & 143.76 & 48.72 \\
\hline CV & 13.2 & 9.0 & 9.9 & 27.5 & 7.2 \\
\hline
\end{tabular}

Equal lowercase letters in the columns do not differ according to the Tukey's test at 5\% probability level. *significant at 5\% probability level. NS: Non-Significant.

Table 6. Mean levels of $\mathrm{N}, \mathrm{P}, \mathrm{K}, \mathrm{Ca}, \mathrm{Mg}$ and $\mathrm{S}$ in sunflower seeds

\begin{tabular}{|c|c|c|c|c|c|c|}
\hline \multirow[t]{2}{*}{ Treatments } & $\mathbf{N}$ & $\mathbf{P}$ & $\mathbf{K}$ & Ca & Mg & $S$ \\
\hline & \multicolumn{6}{|c|}{ 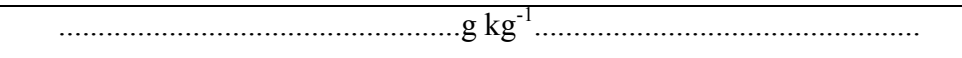 } \\
\hline T1 & $26.8 \mathrm{a}$ & $7.6 \mathrm{a}$ & $12.6 \mathrm{a}$ & $2.4 \mathrm{a}$ & $4.3 \mathrm{a}$ & $1.6 \mathrm{a}$ \\
\hline T2 & $29.0 \mathrm{a}$ & $7.8 \mathrm{a}$ & $11.6 \mathrm{a}$ & $2.0 \mathrm{a}$ & $4.2 \mathrm{a}$ & $1.5 \mathrm{a}$ \\
\hline T3 & $29.0 \mathrm{a}$ & $8.3 \mathrm{a}$ & $12.2 \mathrm{a}$ & $2.0 \mathrm{a}$ & $4.5 \mathrm{a}$ & $1.6 \mathrm{a}$ \\
\hline T4 & $28.0 \mathrm{a}$ & $8.0 \mathrm{a}$ & $12.2 \mathrm{a}$ & $2.0 \mathrm{a}$ & $4.4 \mathrm{a}$ & $1.6 \mathrm{a}$ \\
\hline T5 & $32.4 \mathrm{a}$ & $9.1 \mathrm{a}$ & $12.6 \mathrm{a}$ & $2.2 \mathrm{a}$ & $4.9 \mathrm{a}$ & $1.7 \mathrm{a}$ \\
\hline $\mathbf{F}$ & $0.56^{\mathrm{NS}}$ & $2.32^{\mathrm{NS}}$ & $0.67^{\mathrm{NS}}$ & $1.45^{\mathrm{NS}}$ & $1.79^{\mathrm{NS}}$ & $1.47^{\mathrm{NS}}$ \\
\hline Mean & 29.0 & 8.16 & 12.24 & 2.2 & 4.4 & 1.6 \\
\hline $\mathrm{CV}$ & 21.5 & 10.7 & 9.1 & 15.1 & 16.6 & 8.1 \\
\hline
\end{tabular}

Equal lowercase letters in the columns do not differ according to the Tukey's test at 5\% probability level. NS: Non-Significant 
Table 7. Macronutrient exportation by sunflower seeds

\begin{tabular}{|c|c|c|c|c|c|c|}
\hline \multirow[t]{2}{*}{ Treatments } & \multirow[t]{2}{*}{$\mathbf{N}$} & $\mathbf{P}$ & $\mathbf{K}$ & $\mathrm{Ca}$ & Mg & $\mathrm{S}$ \\
\hline & & \multicolumn{5}{|c|}{...kg ha ${ }^{-1}}$. \\
\hline T1 & $100.1 \mathrm{~b}$ & $28.5 \mathrm{c}$ & $47.4 \mathrm{a}$ & $9.1 \mathrm{a}$ & $16.2 \mathrm{~b}$ & $6.1 \mathrm{a}$ \\
\hline T2 & $140.7 \mathrm{ab}$ & $37.9 \mathrm{~b}$ & $56.3 \mathrm{a}$ & $9.7 \mathrm{a}$ & $20.6 \mathrm{ab}$ & $7.3 \mathrm{a}$ \\
\hline T3 & $129.3 \mathrm{ab}$ & $36.5 \mathrm{~b}$ & $54.4 \mathrm{a}$ & $9.0 \mathrm{a}$ & $19.9 \mathrm{ab}$ & $7.2 \mathrm{a}$ \\
\hline T4 & $122.7 \mathrm{ab}$ & $35.1 \mathrm{bc}$ & $53.5 \mathrm{a}$ & $8.8 \mathrm{a}$ & $19.1 \mathrm{ab}$ & $7.0 \mathrm{a}$ \\
\hline T5 & $165.3 \mathrm{a}$ & $46.6 \mathrm{a}$ & $64.7 \mathrm{a}$ & $11.2 \mathrm{a}$ & $25.0 \mathrm{a}$ & $8.8 \mathrm{a}$ \\
\hline $\mathbf{F}$ & $3.34 *$ & $3.5 *$ & $2.0^{\mathrm{NS}}$ & $1.22^{\mathrm{NS}}$ & $3.27 *$ & $2.35^{\mathrm{NS}}$ \\
\hline Mean & 125.0 & 80.1 & 63.7 & 9.3 & 19.1 & 6.9 \\
\hline CV & 23.6 & 21.0 & 17.8 & 21.4 & 20.6 & 20.4 \\
\hline
\end{tabular}

Equal lowercase letters in the columns do not differ according to the Tukey's test at 5\% probability level. *Significant at $5 \%$ probability level. NS: Non-Significant

Table 8. Mean levels of $\mathrm{B}, \mathrm{Cu}, \mathrm{Fe}, \mathrm{Mn}$ and $\mathrm{Zn}$ in sunflower seeds

\begin{tabular}{|c|c|c|c|c|c|}
\hline Treatments & $\mathbf{B}$ & $\mathbf{C u}$ & Fe & Mn & Zn \\
\hline & \multicolumn{5}{|c|}{. } \\
\hline T1 & $32.8 \mathrm{a}$ & $17.2 \mathrm{a}$ & $65.0 \mathrm{a}$ & $32.4 \mathrm{a}$ & $66.2 \mathrm{~b}$ \\
\hline $\mathbf{T} 2$ & $33.2 \mathrm{a}$ & $16.0 \mathrm{a}$ & $62.8 \mathrm{a}$ & $27.0 \mathrm{a}$ & $70.2 \mathrm{~b}$ \\
\hline T3 & $31.4 \mathrm{a}$ & $15.4 \mathrm{a}$ & $68.4 \mathrm{a}$ & $35.0 \mathrm{a}$ & $72.0 \mathrm{~b}$ \\
\hline T4 & $32.0 \mathrm{a}$ & $19.8 \mathrm{a}$ & $68.0 \mathrm{a}$ & $33.6 \mathrm{a}$ & $75.4 \mathrm{ab}$ \\
\hline T5 & $35.6 \mathrm{a}$ & $20.6 \mathrm{a}$ & $73.4 \mathrm{a}$ & $33.8 \mathrm{a}$ & $89.8 \mathrm{a}$ \\
\hline $\mathbf{F}$ & $0.78^{\mathrm{NS}}$ & $0.79^{\mathrm{NS}}$ & $0.74^{\mathrm{NS}}$ & $1.04^{\mathrm{NS}}$ & $6.04 *$ \\
\hline Mean & 33.5 & 17.8 & 67.6 & 32.2 & 73.3 \\
\hline CV & 12.1 & 27.6 & 15.4 & 21.3 & 11.2 \\
\hline
\end{tabular}

Equal lowercase letters in the columns do not differ according to the Tukey's test at 5\% probability level. *Significant at 5\% probability level. NS: Non-Significant

Seed nutrient levels did not significantly vary with sewage sludge application, except for $\mathrm{Zn}$ (Tables 6 and 7); however, the exported values showed significant differences, except for $\mathrm{K}, \mathrm{Ca}, \mathrm{S}, \mathrm{B}$ and $\mathrm{Mn}$ (Tables 8 and 9).

Nutrient exportation is extremely important to quantify nutrients that are removed from the culture and to replace them, if necessary, in a following planting through comparison with the remaining levels in the soil. Although nutrient demand by sunflower culture was high, its exportation by the seeds is low, i.e. several nutrients return to the soil through leaves, stems, roots and capitula after harvest; thus, the subsequent cultures present high 
Table 9. Micronutrient exportation by sunflower seeds

\begin{tabular}{|c|c|c|c|c|c|}
\hline Treatments & B & $\mathbf{C u}$ & Fe & Mn & Zn \\
\hline & ................. & ........ $\mathrm{g} \mathrm{ha}^{-}$ & .1. & & \\
\hline T1 & $124.7 \mathrm{a}$ & $65.2 \mathrm{bc}$ & $245.6 \mathrm{c}$ & $122.7 \mathrm{a}$ & $247.4 \mathrm{c}$ \\
\hline $\mathbf{T} 2$ & $161.0 \mathrm{a}$ & $77.5 \mathrm{~b}$ & $307.3 \mathrm{~b}$ & $130.9 \mathrm{a}$ & $340.8 \mathrm{~b}$ \\
\hline T3 & $140.0 \mathrm{a}$ & $58.8 \mathrm{c}$ & $310.2 \mathrm{~b}$ & $153.3 \mathrm{a}$ & $321.9 \mathrm{~b}$ \\
\hline T4 & $143.0 \mathrm{a}$ & $86.3 \mathrm{~b}$ & $299.7 \mathrm{~b}$ & $142.9 \mathrm{a}$ & $329.9 \mathrm{~b}$ \\
\hline T5 & $181.0 \mathrm{a}$ & $102.4 \mathrm{a}$ & $376.6 \mathrm{a}$ & $170.2 \mathrm{a}$ & $456.1 \mathrm{a}$ \\
\hline $\mathbf{F}$ & $2.28^{\mathrm{NS}}$ & $3.21 *$ & $90.42 *$ & $1.85^{*}$ & $5.9^{*}$ \\
\hline Mean & 143.8 & 78.0 & 192.3 & 136.7 & 317.7 \\
\hline $\mathrm{CV}$ & 22.2 & 27.7 & 9.0 & 24.1 & 21.7 \\
\hline
\end{tabular}

Equal lowercase letters in the columns do not differ according to the Tukey's test at 5\% probability level. *Significant at 5\% probability level. NS: Non-Significant

productivity. Castro et al. (2005) reported that sunflower plants had reduced nutrient exportation rates and higher dry matter and nutrient levels in plant remnants.

\section{CONCLUSIONS}

The application of $30.4 \mathrm{tha}^{-1}$ of the swage sludge on wet weight basis $\mathrm{t}$ (T5) led to higher vegetative development (height, stem diameter and leaf number) and $\mathrm{Zn}$ levels both in seeds and leaves, compared to the other treatments.

\section{REFERENCES}

Andreoli, C. V., Domaszk, S., Fernandes, F., Lara, A. I. 1997. Proposta preliminar de regulamentação para a reciclagem agrícola do lodo de esgoto no Paraná. Sanare 7, 53-60.

Araujo, F. F., Gil, F. C., Tiritan, C. S. 2009. Lodo de esgoto na fertilidade do solo, na nutrição de Braquiaria decumbens e na atividade desidrogenase. Pesquisa Agropecuária Tropical $39,1-6$
Barros, D. A. S., Peixoto, J. S., Nascimento, C. W. A., Melo, E. E. C. 2002. Conteúdo de nitrogênio e produção de biomassa em milho e feijoeiro em solos submetidos a doses de lodo de esgoto. In: FERTBIO, 3. Resumos, Sociedade Brasileira de Ciência do Solo, Rio de Janeiro, RJ, CD-ROM.

Binder, D. L., Dobermann, A., Sander, D. H., Cassman. K. G. 2002. Biossolids as nitrogen source for irrigated maize and rainfed sorghum. Soil Sci. Soc. Am. J. 66, 531-543.

Biscaro, G. A., Machado, J. R., Tosta, M. S., Mendonça, V., Soratto, R. P., Carvalho, L. A. 2008. Adubação nitrogenada em cobertura no girassol irrigado nas condições de CassilandiaMS. Ciência e Agrotecnologia 32, 1366-1373.

Castro, C., Oliveira, F. A. 2005. Nutrição e Adubação do Girassol. In: Girassol no Brasil. EMBRAPA - SOJA, Londrina, PR, pp: 317-374.

Castro, C., Oliveira, F. A., Veronesi, C. O., Salinet, L. H. 2005. Acumulo de matéria seca, exportação e ciclagem de nutrientes pelo girassol. In: REUNIÃO NACIONAL DE PESQUISA DE GIRASSOL, 16. Resumos, EMBRAPA, Londrina, PR, pp: 29-31. 
CONAMA (Companía Nacional Do Meio Ambiente). 2006. Resolução $N^{o} \quad 375 / 2006$. http://www.mma.gov.br/post/conama/legiano/ Sept 29.

Epstein, E., Bloom, A. J. 2006. Nutrição Mineral de Plantas: principios e perspectives. 2 ed. Planta, Londrina, 403 p.

LANARV, 1988. Análise de corretivos, fertilizantes e inoculantes: métodos oficiais. Ministério da Agricultura, Brasília, 104 p.

Lobo, T. F., Grassi Filho H. 2007. Níveis de lodo de esgoto na produtividade do girassol. R. C. Suelo Nutr. Veg, 7, 16-25.

Malavolta, E. 2006. Manual de Nutrição Mineral de Planta. Agronômica Ceres, São Paulo, 632 p.

Pimentel Gomes, F. 2000. Curso de estatística experimental. 14 ed. Do Autor, Piracicaba, 477 p.

Prado, R. M., Natale, W. 2005. Desenvolvimento inicial e estado nutricional do maracujazeiro em resposta a aplicação de lodo têxtil. Pesquisa Agropecuária Brasileira 40, 621626.
Raij, B. V., Andrade, J. C., Cantarella, H., Quaggio, J. A. 2001. Análise química para fertilidade de solos tropicais 1 ed. INSTITUTO AGRONOMICO - FUNDAÇÃO IAC., Campinas, $285 \mathrm{p}$.

Salvador, J. T. 2006. Reciclagem agrícola de lodo de esgoto tratado no Paraná pelo processo N-vitro: efeitos em solos, plantas, água de percolação e a possibilidade da alteração de sua relação Ca:Mg. Doctoral thesis, Universidade Federal do Paraná, Curitiba, Brazil, 142 p.

SAS Institute 2001. SAS user's guide: statistics, version 8.2, 6 ed., Cary, NC, 943 p.

Taiz, L., Zeiger, E. 2004. Fisiologia vegetal. 3 ed. Artmed, Porto Alegre, 719 p.

Tanaka, R. T. 1981. Nutrição e adubação da cultura do girassol. Informe Agropecuário7, 7476.

Vieira, R. F., Tanaka, R. T., Tsai, S. M., Perez, D. V., Silva, C. M. M. S. 2005. Disponibilidade de nutrientes no solo, qualidade de grãos e produtividade da soja em solo adubado com lodo de esgoto. Pesquisa Agropecuária Brasileira 40, 919-926. 